UNIVERSITY

OF DEBRECEN

FACULTY OF

HeAlTH

NYÍREGYHÁZA

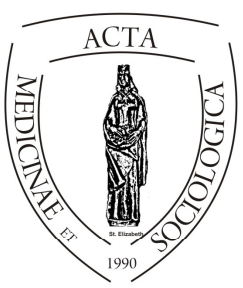

ACTA

MedSoc

VOLUME 6.

2015

\title{
A burnout szindróma vizsgálata a nyíregyházi ápolók körében
}

\section{Nagy Ildikó}

\section{Debreceni Egyetem Egészségügyi Kar}

\begin{abstract}
Background: I would like to identify the factors associated with the signs and symptoms of burnout among nursing staff from an hospital and an eldery home. One of my goals to with my research call the attention the importance of the topic and with my research i would like to improve the quality of the care.

Data and methods: In my survey I used an anonym questionnaire which consists of eighty items which included the socio-demographic data , my own questions, the Ryff's scales of psychological well-being (1995) and the Maslach Burn-out Inventory Human Services (1981). I analysed with SPSS statistic programme. 130 nurses participated in this survey. These surveys were conducted in April-June in 2014. I collect the questionnaire in Nyíregyháza in a hospital and in an eldery home.

Results: The results of studies have shown that more than half of the respondents reached a high or medium levels of burnout. The workers whose working in a chronic care ward had the highest level of burnout My research also showed that the overtime, the death, and caring for the seriously ill cause the biggest stress for the nurses.

Conclusion: My research shows that it would be very important to the nurses get a mental health care and to use the opportunities of the burnout prevention This would be important because it improve the quality of care and the nurses physical and psychological well-being.
\end{abstract}

Keywords: nurse, burnout, well-being 


\begin{abstract}
Absztrakt. Célkitüzés: Nagyon fontosnak tartom, hogy minél nagyobb hangsúlyt fektessünk az ápoló személyzet kiégettségének vizsgálatára, hiszen az ápolók segítő személyek, ezért a lelki megterhelésük igen nagy. Egyik célom, hogy kutatásommal, illetve a téma fontosságára való felhívással az ápolás minőségét javítsam. Adatok és módszerek: Kutatásom során egy három részből álló kérdőívet osztottam ki. A kérdőív az alábbi részekből állt: Maslach Burnout Inventory (MBI), Ryff jóllét skálája, egyéb kérdések. A kérdőíveket a Szabolcs Szatmár Bereg Megyei Kórházak és Egyetemi Oktatókórház aktív és krónikus ellátású osztályain osztottam ki. A Nyíregyháza Városi Református Egyházközség Sóstói Szivárvány Idősek Otthonában is osztottam ki kérdőíveket. Eredmények: A vizsgálatok kimutatták, hogy a megkérdezettek több mint fele a kiégés valamelyik alskáláján magas illetve közepes kiégettségi szintet ért el. Az osztályok ellátási formáját tekintve a krónikus osztályon voltak a legnagyobb százalékban azok a dolgozók, akik a kiégettség valamely alskáláján magas kiégettségi szintet értek el. A kiégés testi tünetei közül a fáradtság jelenik meg a leggyakrabban a vizsgált ápolók körében. Kutatásomból az is kiderült, hogy a vizsgált ápolóknak a túlóra, a halál, és a súlyos betegekről való gondoskodás okozza a legnagyobb stresszt. Az osztályok ellátási formáját tekintve a krónikus osztályon a jóllét minden összetevője alacsonyabb értéket mutatott, mint a többi ellátású osztályon. Következtetések: Kutatásom rávilágít, hogy célszerü lenne az egészségügyi intézményekben az ápolók mentálhigiénés gondozása, illetve a kiégés prevenciós lehetőségeinek kihasználása. Erre szükség lenne mind az ápolás minőségének javítása, mind az ápolók lelki egészségének megörzése érdekében is.
\end{abstract}

Kulcsszavak: ápoló, burnout, osztályok ellátási formája, jóllét

\title{
A kutatás indoklása és célja
}

Nagyon fontosnak tartom, hogy minél nagyobb hangsúlyt fektessünk az ápoló személyzet kiégettségének vizsgálatára, hiszen az ápolók segítő személyek, ezért a lelki megterhelésük igen nagy. Naponta kell megbirkózniuk a testi és érzelmi problémák megoldásával, mely a saját lelki egyensúlyukat is felboríthatja. A saját lelki egyensúlyuk felborulása pedig kihatással van a betegekre és az ápolás milyenségére. Ezért egyik célom, hogy kutatásommal, illetve a téma fontosságára való felhívással az ápolás minőségét javítsam.

Kutatásom másik célja, hogy megvizsgáljam melyek a leggyakoribb okai az ápolói kiégésnek, milyen tényezők játszanak szerepet a kiégésben, van - e összefüggés az iskolai végzettséggel, mindemellett érdekel a kiégés és a pályaelhagyás kapcsolata. Szeretném megvizsgálni mely testi panaszok jelennek meg leggyakrabban a kiégés kapcsán, valamint össze szeretném hasonlítani a kiégés arányát az aktív, krónikus osztályon dolgozó ápolók körében és az idősotthonban 
dolgozó ápolóknál is. Végül szeretném megvizsgálni a kiégés és a pszichológiai jóllét kapcsolatát is.

\section{Szakirodalmi áttekintés}

\section{A burnout kutatásának fejlődése}

Az 1970-80-as években jelent meg a fogalom, ekkor két irányvonalból közelítették meg a jelenséget: a személyiség és a munkahelyi, társas környezet szempontjából. Az 1980-as években jelent meg a Maslach Burnout Inventory kérdöív, melyet Maslach és munkatársai fejlesztettek ki 1982-ben, és lehetővé tette a szélesebb körü adatfelvételt. A kérdőív világszerte elfogadott, elismert és ma is a leggyakrabban használt kérdőív a témában, tehát nagy előrelépést jelentett a kutatásokban. Ezekben a kutatásokban nagy hangsúlyt kapott a stressz, a siker és kudarc aránya, a tanult tehetetlenség, a munkahelyi körülmények és a társas kapcsolatok vizsgálata. Az 1990-es években a munkahely vizsgálatán kívül fontos volt a családi kapcsolatok vizsgálata. Napjainkban három fő tényezőt vizsgálnak: a munkahely körülményeit, a foglalkozás jellegét, valamint a szervezet specifikumait. A kutatások során nagy jelentőséget kapnak a gazdasági szempontok a munkahelyi hiányzások miatt. Megtörtént a különböző országok illetve földrészek összehasonlítása is (Tandary- Kovács 2010).

Magyarországon a 90-es évektől van jelen a fogalom, egyre több kutatási eredménnyel. A kutatások különböző szemszögből közelítik meg a problémát, Kulcsár Zsuzsanna az empátiás kapacitás kimerülését helyezte a középpontba, Oláh Attila a megküzdési stratégiákat vizsgálta a kiégés kapcsán, Szicsek Margit a munkahelyi légkört helyezte a középpontba, míg Kovács Mariann az érzelmi kapcsolatokra helyezi a hangsúlyt (Bordás 2010).

\section{A kiégés okai}

A beteg emberek ápolása egy feszültséggel telített munka, hiszen az emberek szenvedése, a három müszakos munka, a szerepek tisztázatlansága, a korlátozott elörelépési lehetőségek, az alulfizetettség olyan faktorok, melyek pszichológiai problémákat okozhatnak. A túl sok stresszhatás pedig lelki és testi tüneteket okozhat, mely megnehezíti a jelen lévő stressz leküzdését. Az észlelt munkastressz pedig a burnout kockázatát növeli (Pálfi 2006).

Helembai Kornélia szerint a burnout szindróma kialakulásának prediszponáló tényezője az egyén foglalkozás választása, ha ez nem tudatosan történik, hanem ezzel saját hiányosságait szeretné kiegészíteni. Fontosnak tartja még az életről, halálról való felfogását: „Ha valaki az ápolásban a munkája fokmérőjének az élet megmentését tekinti, valószínüleg nehezen birkózik meg az elmúlás, halál 
tényével" (Helembai 2010:39). Az időskorúak ápolása, gondozása kevesebb sikerélményt nyújt, így ezt is a kiégés egyik kockázati tényezőjeként említi meg. Ilyenkor ugyanis irreális elvárásai vannak a beteggel szemben, a kis lépéseket, amelyeket elér, jelentéktelennek tartja, tehát az ápolói attitüdből fakad a probléma. Az emberi tulajdonság egyike az is, hogy fontos számára az elismerés, mely az ápolói munkában nem mindig teljesül, főleg a társadalom részéről. Az intézményi problémák is jelentősek a szindróma kialakulásában, hiszen a nem megfelelő tájékoztatás miatt megjelenhet a kiszolgáltatottság érzése. Ha pedig nem érzik fontosnak magukat az adott munkahelyen, a pályaelhagyás is megjelenhet (Helembai 2010).

A kiégés okaként megemlítésre kerül még a döntéshozatal problematikája is. Hiszen az egészségügyi szakembereknek naponta olyan döntéseket kell hozniuk, melynek súlyos következményei lehetnek és ez óriási külső - belső nyomásként jelenik meg náluk. Tudják, hogy a munkájukat legjobb tudásukhoz mérten kell végezniük, a lehető legkevesebb hibával (Csabai - Molnár 1999).

Nagy Edit leírja, hogy hazánkban a krónikus nővérhiány miatt az egészségügyben fokozottan megjelenik a kiégés, és minél több tényező áll fenn egyidejüleg, mely a kiégést segíti, annál nagyobb a veszélye, hogy létre is jön. Ilyen tényezőnek nevezi meg a munkarendet, a szerepfeszültséget, a váratlan eseményeket, a munkahelyi kudarcot, melyek gyorsíthatják a folyamatot (Nagy 2005).

Utolsó okként pedig az altruista kapacitás kimerülését említeném meg. Az altruizmus tulajdonképpen az empátia interperszonális kimenetele, és így az ápolás is egy altruista tevékenységnek tekinthetö. Az altruizmus azonban nem lehet folytonos, kiégéshez vezethet, ha a kapacitása kimerül, viszont nem feltétlenül jelenik meg. Kulcsár szerint: „Az emberi pszichés teljesitöképesség legmagasabb funkciójáról van szó, amelynek senki sincs állandó birtokában, megélésükre azonban minden embernek megvan az esélye. E kapacitás rendkivül sérülékeny, visszaélést nem tür, könnyen kimerül. A segitö hivatás tehát, miközben az ember legkomplexebb késztetéseit és legjobb erőit mozgósitja, veszély forrása is. A genuin altruizmus kapacitásának kimerülése, e legjobb erökkel való visszaélés a kiégés szindrómájához vezet." (Kulcsár 2002:207)

\footnotetext{
${ }^{1}$ Helembai Kornélia (2010): Általános ápoláslélektan. Medicina Könyvkiadó Zrt, Budapest.

${ }^{2}$ Kulcsár Zsuzsanna (2002): Egészségpszichológia. ELTE Eötvös Kiadó Budapest.
} 


\section{A kiégés szakaszai és tünetcsoportjai}

A kiégés nem egy pillanatnyi állapot, hanem egy ciklikus folyamat, melynek szakaszai Edelwich Brodsky és Georg E. Becker felosztása szerint a következőek:

1. az idealizmus szakasza

2. a realizmus fázisa

3. a stagnálás vagy kiábrándulás fázisa

4. a frusztráció fázisa

5. az apátia fázisa

(Pálfi 2007).

Az idealizmus szakaszában a lelkesség, a munkatársakkal való kapcsolattartás, a túlazonosulás jellemző. A realizmus fázisában a részvét és távolságtartás közötti egyensúly megteremtése a cél, míg a kiábrándulás fázisában csak a legszükségesebbre korlátozódik a kapcsolat és az érdeklödés is csökken. A frusztráció fázisában egyre jobban megjelenik a negatív beállítódás, a kliensek becsmérlése, a hivatás értelmének és tudásának kétségbe vonása. Az apátia fázisában a hangulat ellenséges lesz, a munkavégzés rutinszerüvé válik (Ónody 2001).

A kiégés tünetcsoportjai a következőek: emocionális kimerülés (lehangoltság érzése, reménytelenség, ingerlékenység, harag), fizikális kimerültség (krónikus fáradtság, gyengeség, alvászavar, fejfájás, hányinger), mentális kimerültség (negatív hozzáállás), deperszonalizáció (elszemélytelenedés, társadalmi kontaktusok beszükülése), csökkent teljesítöképesség és teljesítménnyel való elégedetlenség (tehetetlenség, sikertelenség, túlterheltség miatt) (Helembai, 2010).

A kiégés első tünete az ellátás minőségének romlása lehet, melyet a munkával való elégedetlenség követ. Megjelennek a munkahelyi hiányzások, sőt ha a munkahelyén tartózkodik, akkor is inkább távol marad a betegektől. Következő lépésként állásváltoztatás jöhet szóba, de ha ez sem segít a helyzeten, megjelennek a pszichoszomatikus betegségek, eközben a családi feszültség is nő. Kialakulhat depresszió, alvászavar, majd a problémák oldására súlyos esetben alkohol és drogfogyasztás is előfordulhat. (Csabai - Molnár:1999)

Egy másik felosztás szerint a kiégés egy 12 lépcsőből álló ciklikus folyamat. A folyamat stádiumai összemosódnak, a szakaszok a személyiségtől függően különböző intenzitásúak.

1. szakasz: Bizonyításkényszer: az adottságok képességek bizonyítása. Ha viszont ez kényszeres lesz, veszélyeztetheti a lelki egészséget.

2. szakasz: Fokozott erőfeszítés: állandó túlterheltség van jelen, a feladatokat nem képesek másnak átadni. A teljesítmény folyamatosan nő, emiatt krónikus fáradtság jelenig meg, mely viszont az eredményességet csökkenti. 
3. szakasz: Saját igények elhanyagolása: a fókuszba a munka kerül, a személyes életre kevesebb idő jut. Azok az események, amelyekből a személy feltöltődött, pozitív élményeket jelentett számára, egyre jobban eltűnnek az életéből.

4. szakasz: Az igények, konfliktusok elhanyagolása: próbálják elrejteni a környezetük elől a fáradtságot, a problémákat. Ebben a szakaszban még tudják, hogy jobban oda kellene figyelniük saját magukra.

5. szakasz: Az értékrend átalakulása: egyre inkább egyedül maradnak, mert a barátaikat, családjukat már csak teherként érzik életükben. Nem tudnak különbséget tenni, hogy mi fontos és kevésbé fontos életükben.

6. szakasz: A problémák eltagadása: a gondolkodásuk és érdeklődésük beszükül, csupán a feladatukra koncentrálnak. A kapcsolat a külvilággal fokozatosan megszünik.

7. szakasz: Visszahúzódás: elmagányosodástól való félelem jelenik meg, egyre kevesebbet kerülnek kapcsolatba másokkal.

8. szakasz: Magatartásváltozás: kritikaként él meg minden véleményt, szélsőségek jellemzik ezt az időszakot ( pl. falánkság vagy fogyókúra).

9. szakasz: Deperszonalizációs jelenségek: a belső világgal megszünik a kapcsolat, idegenként tekint magára.

10. szakasz: Belső üresség érzése: a belső ürességet szeretné eltörölni, megpróbálja feltölteni magát, általában káros szenvedélyek segítségével (drog, futó kalandok).

11. szakasz: Depresszió: kimerültség jelenik meg, a legkisebb dolgot is hatalmas teherként élik meg. A fáradtság pihenés ellenére sem szünik, életét örömtelennek tartja. Fennáll az öngyilkosság veszélye is.

12. szakasz: Teljes kiégettség, kimerültség: pszichoszomatikus betegségek alakulhatnak ki, illetve a pszichés és szomatikus tünetek olyan súlyosan léphetnek fel, hogy az életet veszélyeztető állapot is kialakulhat (Hézser 1996).

A burnout tünetegyüttes kialakulásában nagy szerepet játszik a depresszív személyiségstruktúra, a pozitív visszacsatolás hiánya és az emocionális túlterheltség (Nagy 2007).

\section{A kiégés következményei}

Hárdi István az egyik legnagyobb problémának tartja a munka elrutinosodását, az ápolás mechanikus végzését. Ekkor bár minden feladat végrehajtódik, a beteg kimarad az ápolásból. Nem a beteg lesz a középpontban, hanem az ápolás, mint tevékenység. Az ápolás elszemélytelenedése pedig veszélyezteti a beteg - nővér 
kapcsolatot, a feszültségek ennek hatására halmozódni fognak. A kommunikáció hivatalos, érzelmektől mentes lesz, ezért az érzelmek verbális levezetődésének, az érzelmek hiánya - alexithymia - a pszichoszomatikus betegségek kialakulását segítik elő. Emellett a nővérek hüvössége a gondozottakra is hatással vannak. A betegek ugyanis elesettségükben elvárják a törődést, a szeretetet (Hárdi 1998).

Az emocionális kimerültség voltaképpen az empátiás kapacitás kimerülése, melynek következménye a deperszonalizáció. Az empátia kimerülése az érett személyiség funkciók csökkenésével is együtt jár, tehát csökkeni fog a problémamegoldó képesség, a kreativitás, melyek nagyon fontos tényezői az ápolásnak (Kulcsár 2002).

\section{Kutatási módszerek}

\section{A kutatás során alkalmazott kérdóívek}

Kutatásom során egy három részből álló kérdőívet osztottam ki, melynek kitöltése anonim és önkéntes volt. A kérdőív kitöltése kb. 10 percet vett igénybe. A kérdöív az alábbi három részből állt:

\section{a) Maslach Burnout Inventory (MBI)}

A kiégés mértékének a felmérésére a Maslach Burnout Inventory standard kérdőívet használtam. A kérdőív 3 elemből épül fel, vizsgálja az érzelmi kimerülést, a deperszonalizációt és az egyéni teljesítőképességet. A kérdőívben összesen 22 állítás található, melyet a gyakoriság és az intenzitás szempontjából is értékelnek a kérdőív kitöltői. A gyakoriságot egy hat fokozatú skálán, míg az intenzitást egy hét fokozatú Likert-skálán értékelik a válaszadók. A legritkább (soha) és leggyengébb (egyáltalán nem) választ nullával jelölik, a leggyakoribb (minden nap) választ hattal, a legintenzívebbet (igen erős) héttel jelölik.

\section{b) Ryff jóllét skálája}

Kutatásom második része Ryff jóllét skáláját tartalmazza, melyben 18 állítást kell értékelni a válaszadóknak egy hat fokozatú Likert- skálán. A kérdőív a jóllét hat faktorát - autonómia, környezet uralása, személyes fejlődés, másokkal való jó kapcsolat, életcél, önelfogadás - tartalmazza és minden faktorhoz három kérdés tartozik.

c) Egyénileg szerkesztett kérdöiv

Kutatásom harmadik részében egy saját szerkesztésủ kérdőívet állítottam össze, melyben demográfiai kérdéseket (nem, kor, iskolai végzettség) és a kiégés kutatására irányuló kérdéseket fogalmaztam meg. 


\section{Mintaválasztás, elemzési módszerek}

A kérdőíveket a Szabolcs Szatmár Bereg Megyei Kórházak és Egyetemi Oktatókórház aktív és krónikus ellátású osztályain osztottam ki. A Nyíregyháza Városi Református Egyházközség Sóstói Szivárvány Idősek Otthonában is osztottam ki kérdőíveket, ezeket külön csoportban elemeztem, nem tekintettem sem krónikus, sem aktív osztálynak. Összesen 250 db kérdöívet hagytam az osztályokon és az Idősotthonban 2014. április 18 és 2014. június 30. között, melyből 160 db kitöltött kérdőívet kaptam vissza. Ezekből 130 db kérdőív volt értékelhető. Az aktív osztályon 50 fö a krónikus osztályon 43 fö és az idősotthonban 37 fö töltötte ki értékelhetően a kérdőívet.

Kutatásomba az intézményekben ápolóként dolgozó személyeket vontam be. Statisztikai elemzésem módja: leíró statisztika. Az elemzéshez az alábbi statisztikai módszereket alkalmaztam: átlag, gyakoriság, korrelációs vizsgálatok, varianciaanalízis.

\section{Eredmények és megbeszélés}

Eredményeimet a $130 \mathrm{db}$ visszakapott értékelhető kérdőívből készítettem el, melyből $50 \mathrm{db}(38,5 \%)$ aktív osztályon, 43 db (33,1\%) krónikus osztályon, 37 db $(28,5 \%)$ idősotthonban került kitöltésre. A teljes minta osztálytípusonkénti százalékos alakulását a lenti kördiagramon ábrázolom. A minta $86 \%$-a nő, a $14 \%$-a férfi.

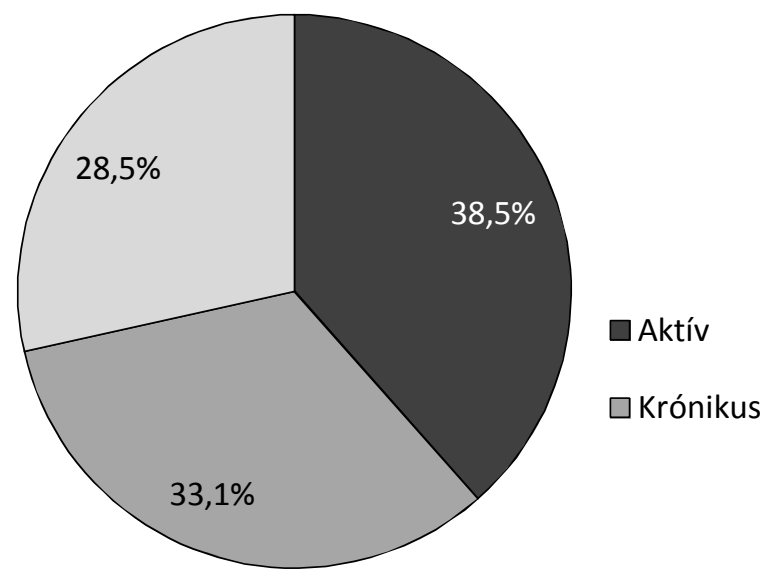

1.ábra: Osztálytípusok százalékos alakulása. 


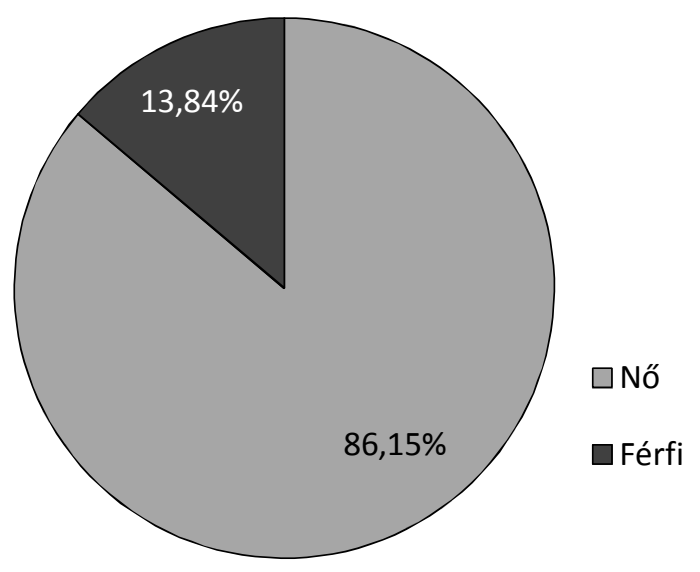

2.ábra: Nemek aránya.

\section{A kiégés mértéke az egész mintát vizsgálva}

Az MBI elemzését az egész mintára elvégeztem. A kiégés három összetevőjénél kapott pontok átlagai alapján egyértelmüen elmondható, hogy a minta egésze a közepesen kiégett kategóriába tartozik.

A magasan kiégett kategóriába a minta 20\%-a tartozott az érzelmi kimerülés és elszemélytelenedést vizsgálva, 40\%-a az egyéni teljesítménycsökennést vizsgálva.

\section{A kiégés foka osztálytípusok szerint}

A 3. ábrán a kiégés magas fokát mutató személyek százalékos megoszlása látható az osztályok ellátási formája szerint, a gyakoriságot vizsgálva. Az érzelmi kimerülés szempontjából az osztálytípusok közül a krónikus osztályon dolgozó ápolók közül mutatják legtöbben a kiégés magas fokát, ugyanis ott a dolgozók 37,2\%-a esik a magas kiégettségü kategóriába, míg az idősotthonban 21,6\%, az aktív osztályon 18\%-uk. Az elszemélytelenedést tekintve az osztálytípusok esetében a krónikus osztályon dolgozó ápolók közül mutatják legtöbben a kiégés magas fokát, ugyanis ott a dolgozók 27,9\%-a esik a magas kiégettségü kategóriába, míg az idősotthonban 21,6\% és az aktív osztályon 14\%-uk. Az egyéni teljesítménycsökkenést vizsgálva osztálytípusok közül a krónikus osztályon dolgozó ápolók közül mutatják legtöbben a kiégés magas fokát, ugyanis ott a dolgozók 62,8\%-a esik a magas kiégettségü kategóriába, míg az aktív osztályon 34\% és az idősotthonban $27 \%$-uk. 


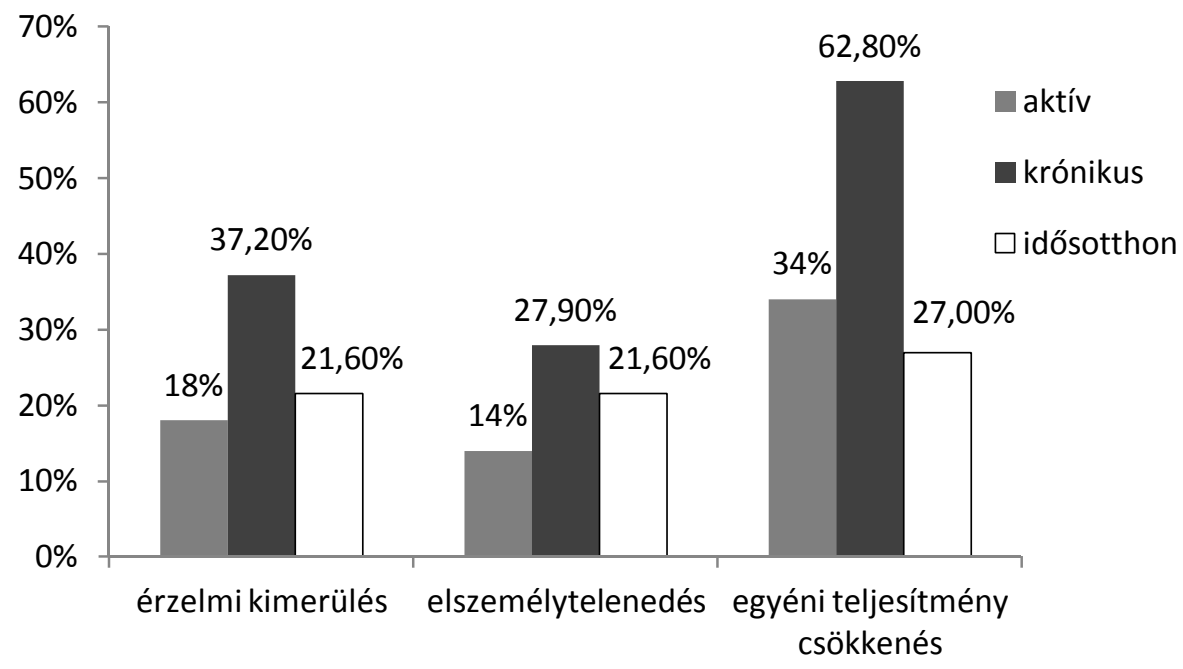

3.ábra: A kiégés magas fokát mutatató személyek százalékos megoszlása az osztályok ellátási formája szerint, a gyakoriságot figyelembe véve.

A 4. ábrán a kiégés magas fokát mutató személyek százalékos megoszlása látható az osztályok ellátási formája szerint, az intenzitást vizsgálva. Az érzelmi kimerülés szempontjából az idősotthonban dolgozó ápolók mutatják legtöbben a kiégés magas fokát, ugyanis ott a dolgozók 18,9\%-a esik a magas kiégettségü kategóriába, a krónikus osztályon 16,3\% és az aktív osztályon 14\%-uk. Az elszemélytelenedést tekintve a krónikus osztályon dolgozó ápolók mutatják legtöbben a kiégés magas fokát, ugyanis ott a dolgozók 25,6\%-a esik a magas kiégettségü kategóriába, míg az idősotthonban $24,3 \%$ és az aktív osztályon $16 \%$-uk. Az egyéni teljesítménycsökkenést vizsgálva a krónikus osztályon dolgozó ápolók mutatják legtöbben a kiégés magas fokát, ugyanis ott a dolgozók 69,8\%-a esik a magas kiégettségü kategóriába, míg az aktív osztályon 36\% és az idősotthonban $24,3 \%$-uk. 


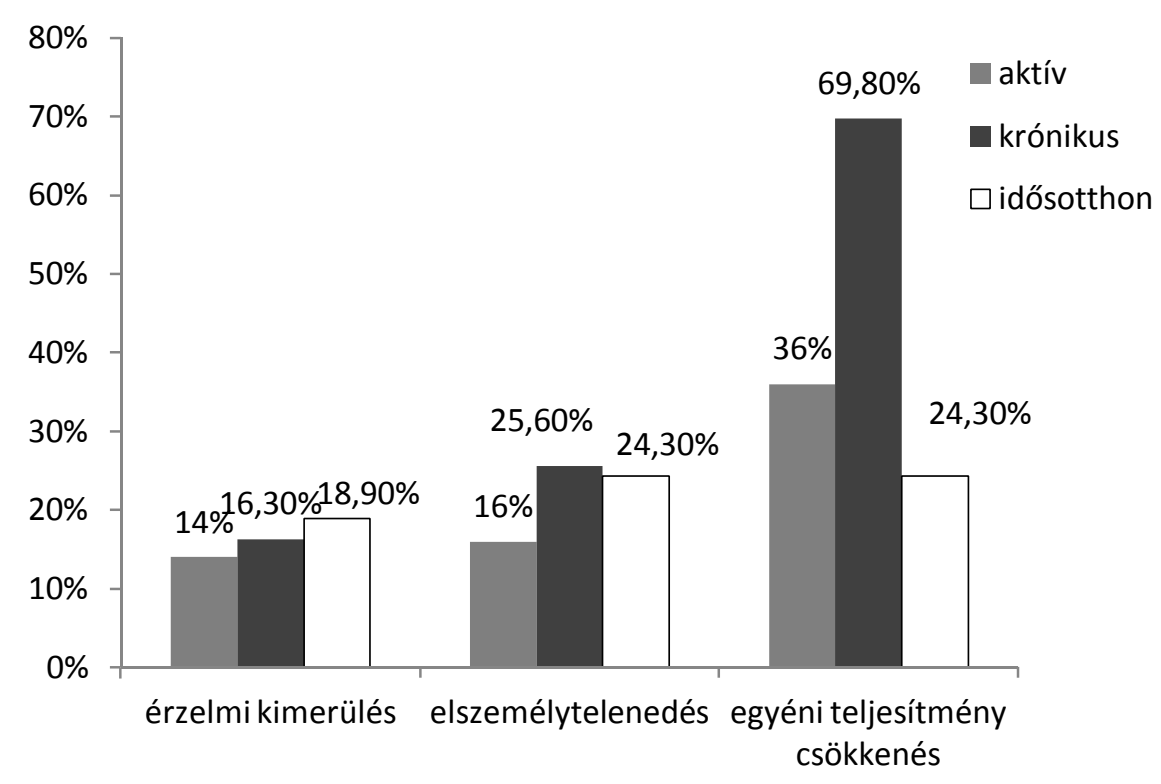

4.ábra: A kiégés magas fokát mutatató személyek százalékos megoszlása az osztályok ellátási formája szerint, az intenzitást figyelembe véve.

Az osztályok összehasonlításánál az átlagot vizsgálva a gyakoriság és az intenzitás szempontjából is, a kiégés mindhárom összetevője nagyobb értéket mutatott a krónikus osztályon, mint az aktív osztályon és az idősotthonban. A kiégés magas fokát mutató személyek legnagyobb arányban a krónikus osztályon vannak a gyakoriság tekintetében a kiégés mindhárom alskáláját vizsgálva. Az intenzitást vizsgálva az érzelmi kimerülést és egyéni teljesítménycsökkenést tekintve, a krónikus osztályon vannak a legnagyobb arányban azok, akik a kiégés magas fokát mutatják, míg az elszemélytelenedést tekintve az aktív osztályon vannak a legnagyobb arányban azok, akik a kiégés magas fokát mutatják. Az egyéni teljesítménycsökkenést vizsgálva az osztályok között szignifikáns eltérés igazolható. Pálfi felmérésében, melyet Pécsen 805 fővel végzett el 2007-ben, megállapította, hogy a krónikus osztályon dolgozó ápolók között magasabb a kiégettség aránya (2,9\%), mint aktív osztályon dolgozó ápolók között (0,6\%) (Pálfi 2007).

Szicsek Margit 88 fó ápoló kiégettségét vizsgálta. Ebből 64 fő szociális otthonban, 24 fö hospice otthonban dolgozott. A kiégettségi mutatókat tekintve a szociális otthonokban alacsonyabb értéket kaptak, mint a krónikus ellátású kórházi osztályokon. (Szicsek 2004)

Úgy gondolom, hogy nagy szerepet játszik a súlyos, gyakran gyógyíthatatlan betegek ápolása, a kevesebb sikerélmény szerzése abban, hogy a krónikus osztá- 
lyon dolgozó ápolók körében magasabb kiégési mutatókat kaptam. Mindezek mellett úgy vélem, hogy a krónikus osztályon dolgozó ápolóknak még nagyobb empátiát kell tanúsítaniuk a betegek felé, mely egy idő után kimerítő lehet.

\section{A pályaelhagyás és a burnout- szindróma}

A válaszadók 33\%-a gondolt már rá, hogy pályát változtat. Az osztályok ellátási formája szerint a krónikus osztályon volt a leggyakoribb a pályaelhagyás gondolata, ugyanis majdnem a megkérdezettek fele (46\%) gondolt már a pályaelhagyásra, ami az aktív osztályhoz (28\%) és az idősotthonhoz (24\%) képest közel a kétszerese.

Az 5. ábrán jól látszik, hogy az ápolók azon csoportja, akiknél a pályaelhagyás gondolata megjelent, magasabb kiégettségi szinttel rendelkezik. Magasabb átlagpontszámot ért el a csoport az érzelmi kimerülés és az elszemélytelenedés tekintetében, és alacsonyabbat az egyéni teljesítménycsökkenésnél, mint azok, akik a pályaelhagyás gondolatával még nem foglalkoztak. Ahogy korábban már megfogalmaztam, a magas pontszám az érzelmi kimerülés és az elszemélytelenedés tekintetében, és az alacsony pontszám az egyéni teljesítménycsökkenésnél kiégésre utal. Egy kétmintás T- próbát is végeztem, hogy megbizonyosodjak eredményeim valósságáról. Az eljárás kimutatta, hogy van szignifikáns különbség a pályaelhagyás gondolatával foglalkozó és nem foglalkozó ápolók csoportja között az érzelmi kimerülés és az egyéni teljesítménycsökkenés tekintetében is.

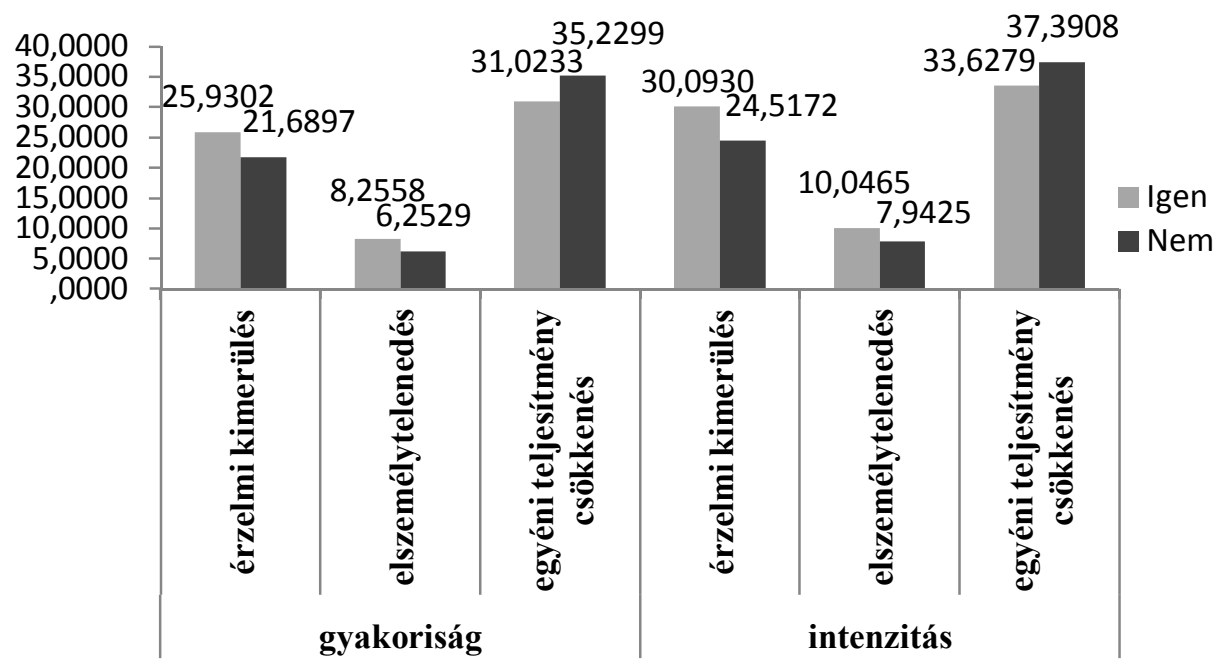

5.ábra: A pályaelhagyás gondolata és a kiégés egyes összetevőinek alakulása a gyakoriság és az intenzitás alapján. 


\section{A kiégés leggyakrabban megjelenő testi tünetei}

A 6. ábrán a kiégés leggyakoribb testi tüneteit mutatom be, a válaszadók besorolása szerint. A válaszadók eggyel jelölték azt a panaszt amit naponta tapasztalnak, héttel amit soha. Az ábrán jól látszik, hogy a fáradtságot jelölték a legyakoribb fizikai tünetnek (átlag: 2,96). A második leggyakoribb tünetnek az izzadást (átlag: 4,12) és fejfájást (átlag: 4,12 ) jelölték a válaszadók.

Megvizsgáltam azt is, hogy melyik tünetet jelölték a legtöbben naponta és hetente többször, ezt a 7. ábrán ábrázolom. A fáradtságot napi tünetnél a legtöbben jelölték meg (33 fö). A hetente többször megjelenő tünetek közül is legtöbben jelölték meg a fáradtságot, illetve a fejfájást (28 fö). Naponta és hetente többször megjelenő tünetként kimagaslóan a fáradtságot jelölték meg a legtöbben (61 fö), ezután az izzadást (39fö) és az ízületi fájdalmat (38fö) jelölték meg második és harmadik leggyakoribb tünetként.

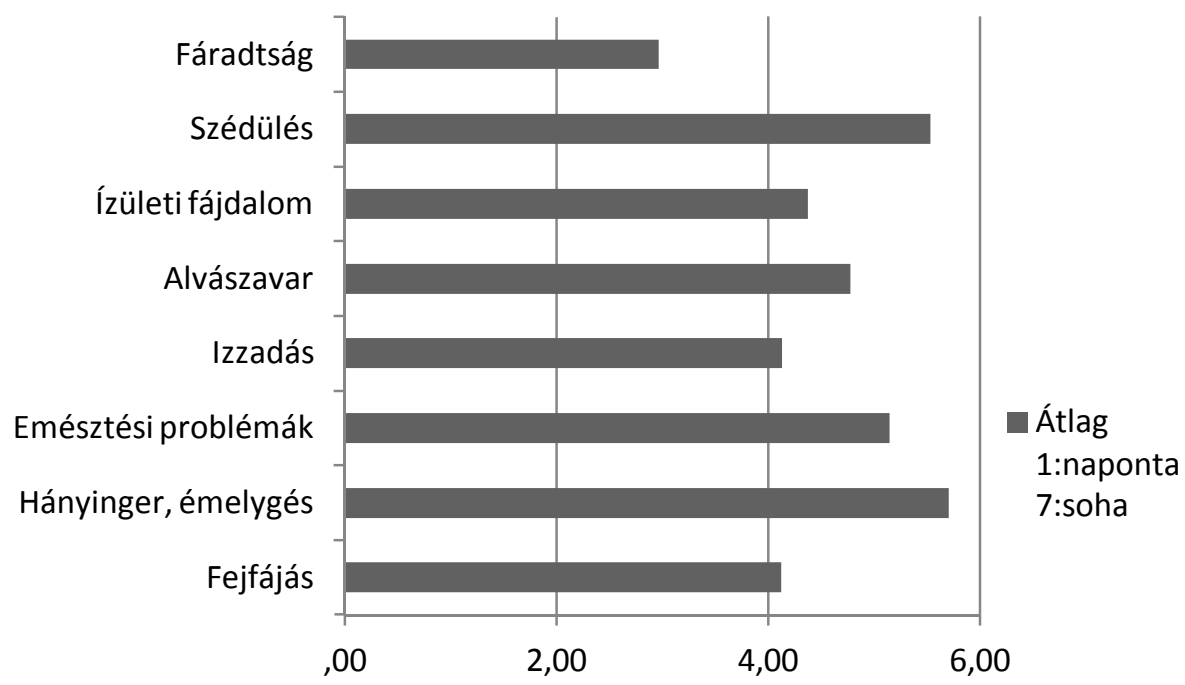

6.ábra: A kiégés fizikai tünetei átlag szerint. 


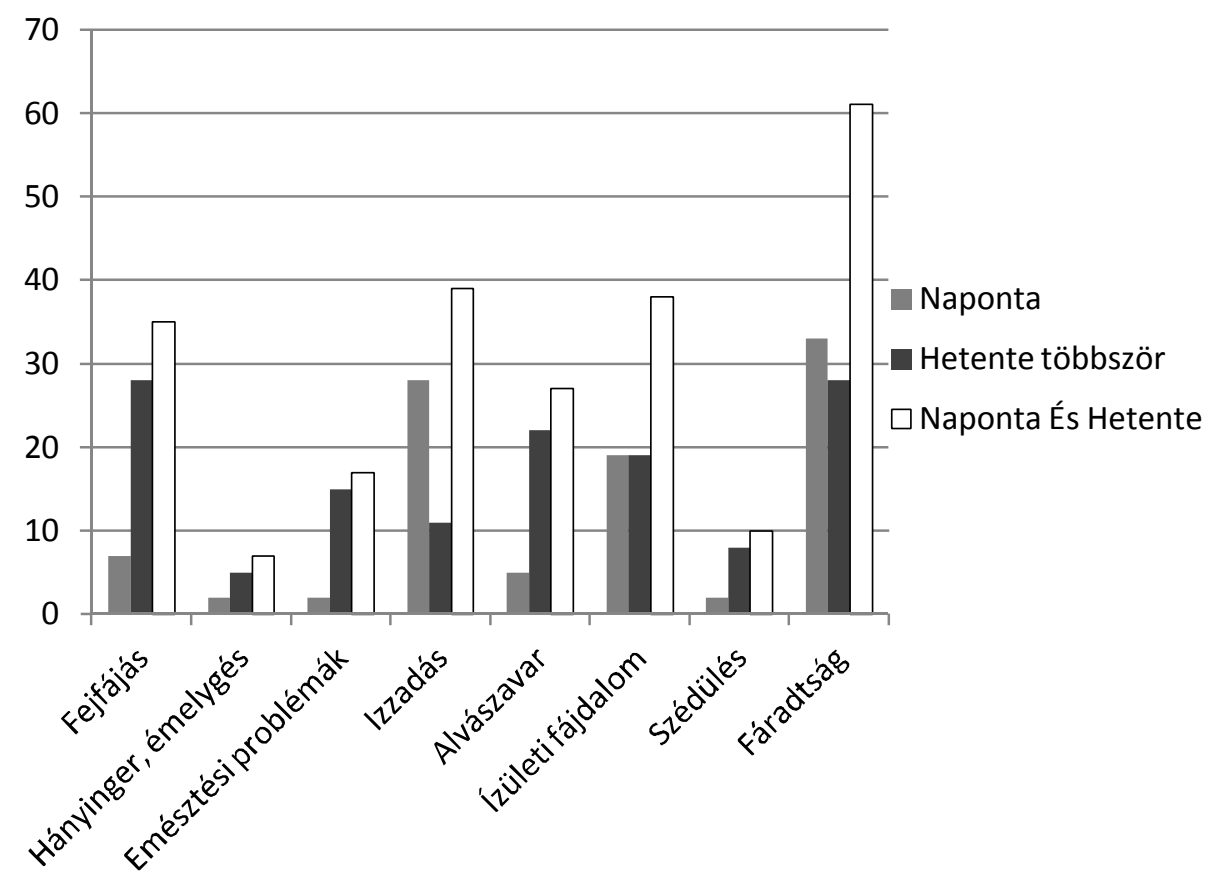

7.ábra: A kiégés fizikai tünetei gyakoriság szerint.

A fenti elemzésből egyértelműen kiderül, hogy a válaszadók a fáradtságot észlelik a leggyakrabbban. Ennek oka véleményem szerint a személyzet hiánya, a túlterheltség és a három müszakos munkarend lehet. A három müszak megterhelő a szervezet számára a normál alvás ébrenlét felborul, emiatt alvászavar jelentkezhet. A nappali alvás nem olyan pihentető, mint az éjszakai. A fáradtság a munkahelyi motivációt is befolyásolja, a lelkesedés csökken, az aktivitás romlik, koncentrációzavar jelentkezhet a teljesítmény és a hangulat is romlik. Ezek pedig nagyon fontosak az ápolói munkában. Az alváshiányhoz ráadásul szorongás és ingerlékenység is társul. Az állóképesség növelésével a fáradtság csökkenthető, könnyebben leküzdhető a napi fizikai megterhelés.

\section{A legnagyobb stresszt kiváltó tényezők}

Eredményeim bemutatását a felmért ápolók válaszainak alapján az egyes stresszkeltő tényezők átlagának ismertetésével kezdeném. Ezeket az eredményeket az 1. táblázatban mutatom be. Az idősotthonban a legnagyobb stresszt az anyagi megbecsültség hiánya, a súlyos betegekröl való gondoskodás és a sikertelenség érzése okozza. A krónikus ellátású osztályon a legnagyobb stresszkeltő tényező a halál és a munkahelyi légkör. Az aktív ellátású osztá- 
lyon a legnagyobb stresszt a túlóra, a halál és a megbecsülés alacsony foka okozza. A stresszkeltő tényezők nem egységesek osztálytípusonként. Az egész mintára nézve a legnagyobb stresszkeltő tényezőnek az átlagot tekintve a túlórát és a halált jelölték meg a válaszadók.

\begin{tabular}{|l|c|c|c|c|}
\hline & Aktív & Krónikus & Idősotthon & Átlag összes \\
\hline anyagi megbecsültség hiánya & 5,18 & 4,74 & $\mathbf{6 , 3 6}$ & 5,35 \\
\hline súlyos betegröl való gondoskodás & 5,13 & 5,67 & $\mathbf{5 , 9 1}$ & 5,54 \\
\hline a halál & $\mathbf{6 , 0 2}$ & $\mathbf{5 , 9 3}$ & 5,79 & $\mathbf{5 , 9 3}$ \\
\hline munkahelyi körülmények & 5,64 & 5,49 & 5,58 & 5,57 \\
\hline megfeszített munkatempó & 4,98 & 5,00 & 4,94 & 4,98 \\
\hline túlóra & $\mathbf{6 , 4 7}$ & 5,74 & 5,48 & $\mathbf{5 , 9 4}$ \\
\hline sikertelenség érzése & 5,73 & 5,74 & $\mathbf{6 , 2 7}$ & 5,88 \\
\hline rutincselekvések & 5,84 & 5,33 & 5,58 & 5,59 \\
\hline munkahelyi légkör & 5,78 & $\mathbf{6 , 1 4}$ & 5,18 & 5,74 \\
\hline megbecsülés alacsony foka & $\mathbf{6 , 0 2}$ & 3,91 & 5,15 & 5,03 \\
\hline
\end{tabular}

1.táblázat: A stresszt okozó tényezők átlaga az osztályok ellátási formája szerint.

Az alábbi ábrán azoknak a válaszadóknak a számát mutatom be, akik a felsorolt stressz kiváltó tényezőkre magas $(7,8,9)$ pontszámot adtak. A táblázatban jól látszik, hogy a válaszadók közül legtöbben a túlórát jellemezték úgy, mint legnagyobb (10 pont) stresszt kiváltó tényezőt. Ezután az anyagi megbecsültség hiánya és a halál okozta a legtöbbeknek a legnagyobb stresszt. Úgy gondolom fontosabb, hogy a magas pontszámot adó válaszadók összegét megvizsgáljuk az egyes tényezőknél, hiszen így a valóban magas stresszt okozó tényezőket kapjuk meg. Így a válaszadók legtöbben a túlórát jelölték meg, mint a legnagyobb stresszkiváltó tényezőt, ezután következett a halál és a súlyos betegekről való gondoskodás. 


\begin{tabular}{|l|c|c|c|c|}
\hline & 8 pont & 9 pont & 10pont & Összesen \\
\hline $\begin{array}{l}\text { anyagi megbecsültség } \\
\text { hiánya }\end{array}$ & 4 & $\mathbf{1 5}$ & $\mathbf{2 1}$ & 40 \\
\hline $\begin{array}{l}\text { súlyos betegröl való gon- } \\
\text { doskodás }\end{array}$ & $\mathbf{1 4}$ & 14 & 15 & $\mathbf{4 3}$ \\
\hline a halál & 12 & $\mathbf{1 6}$ & $\mathbf{1 8}$ & $\mathbf{4 6}$ \\
\hline munkahelyi körülmények & 11 & 14 & 4 & 29 \\
\hline megfeszített munkatempó & $\mathbf{1 4}$ & 8 & 10 & 32 \\
\hline túlóra & 13 & 10 & $\mathbf{2 5}$ & $\mathbf{4 8}$ \\
\hline sikertelenség érzése & $\mathbf{1 8}$ & 11 & 9 & 38 \\
\hline rutincselekvések & 12 & 11 & 8 & 31 \\
\hline munkahelyi légkör & 9 & 12 & 13 & 34 \\
\hline $\begin{array}{l}\text { megbecsülés alacsony } \\
\text { foka }\end{array}$ & 11 & 9 & 13 & 33 \\
\hline
\end{tabular}

2.táblázat: A válaszadók száma az egyes stresszkeltő tényezőknél.

Kimagasló különbség nem volt az egyes tényezők között a vizsgálat során. Eredményeim a túlórát, a halált és a súlyos betegekröl való gondoskodást mutatták meg, mint a legnagyobb stresszkeltő tényezőt. Az eredmény, föleg az, hogy a túlóra áll az első helyen, meglepő volt számomra. Az okokat tekintve, hogy mi lehet ennek a hátterében, arra a következtetésre jutottam, hogy azért érezhetik az ápolók a túlórát ekkora problémának, mert így még kevesebb idő jut a családra, a magánéletre, a szórakozásra, pihenésre stb. Ezek pedig nagyon fontos tényezők ahhoz, hogy az ápolók lelkileg pozitívan feltöltődjenek, a munkahelyi nehézségeket könnyebben leküzdjék.

\section{Hogyan alakul a pszichológiai jóllét az osztályok ellátási formája szerint és milyen kapcsolatban van a kiégéssel?}

Fontosnak tartom, hogy a pszichológiai jóllétet is megvizsgáljam a kiégéssel kapcsolatban, ugyanis úgy gondolom, van összefüggés a kettő között. A deperszonalizáció megnehezíti a pozitív kapcsolat kialakítását másokkal, az egyéni teljesítménycsökkenés az életcél és a személyes fejlődés akadályozója lehet. A kiégés azon szakaszában, ahol a depresszió is megjelenik, az önelfogadás alacsonyabb lehet.

Az alábbi ábrán a vizsgálatomban felmért ápolók pszichológiai jóllétét mutatom be a különböző ellátású osztályok között. A jóllét összetevőinek eredményét (autonómia, környezet uralása, személyes fejlődés, másokkal való jó kapcsolat, életcél, önelfogadás) összehasonlítom Ryff eredményeivel, melyet 321 különbözö 
életkorú személy között mért fel 1989-ben. A krónikus ellátású osztályon a jóllét minden összetevője alacsonyabb értéket mutatott, mint az aktív ellátású osztályon, illetve az idősotthonban. Ryff eredményeihez képest is alacsonyabb értéket mutatott a pszichológiai jóllét minden összetevője a krónikus ellátású osztályon. A varianciaanalízis szignifikáns különbséget mutatott az osztályok között a személyes fejlődés, másokkal való jó kapcsolat és az életcél tekintetében.

A krónikus ellátású osztályokon a kevesebb sikerélmény, a súlyos betegek ápolása, egy idő után érzelmi kiüresedést okozhat, a deperszonalizáció miatt a másokkal való jó kapcsolat csökken, az empátiás képességgel együtt. A sikerélmény csökkenésével, illetve a tehetetlenség érzése miatt a jelentéktelenség érzése nőhet, mely az életcélok az elképzelések csökkenéséhez vezethet.

A személyes fejlődés a vizsgálatomban mindhárom ellátási formájú osztálynál jóval alacsonyabb értéket mutat Ryff eredményeihez képest. A személyes fejlődésben elért alacsony pontszám utalhat arra, hogy a felmért ápolók kevésbé nyitottak a fejlődésre, nem érzik úgy, hogy szakmailag előrébb juthatnak. Tapasztalataim szerint a megkérdezett ápolóknak kevés lehetőségük van a fejlődésre, a ranglétrán való feljebblépésre, amely miatt egy idő után csökkenhet a nyitottságuk az új ismeretek megszerzésére, úgymond befásulnak.

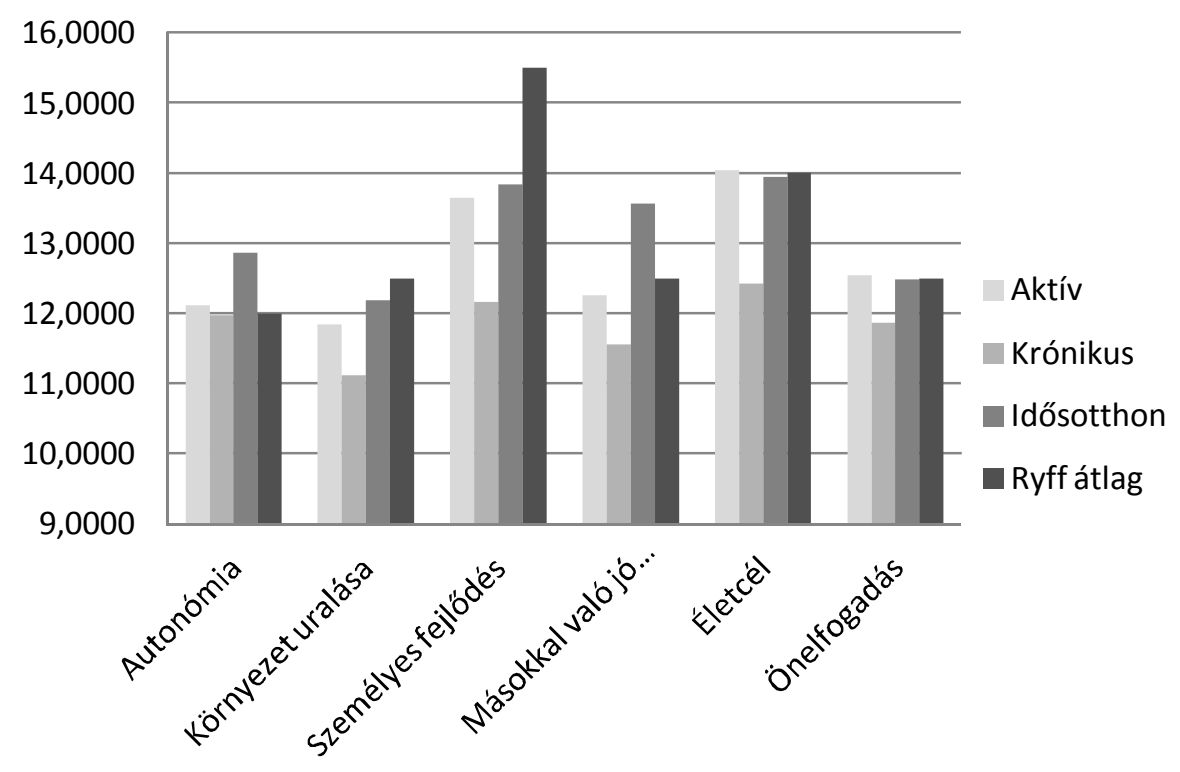

8.ábra: A pszichológiai jóllét alakulása a különböző ellátású osztályokon. 
A kiégés összetevői és pszichológiai jóllét komponensei közötti korrelációs vizsgálatot végeztem. Egyik alskálán belül sem volt kimutatható kapcsolat a kiégés és a jóllét között.

\section{Következtetések és javaslatok}

A krónikus osztályokon magasabb a kiégés aránya, mint más osztályokon. Ennek csökkentése érdekében egy lehetséges megoldási módként látom azt, hogy az egészségügyi dolgozók bizonyos időközönként az osztálytípusok között cserélődjenek, krónikus ellátású osztályról kerüljenek aktív ellátású osztályra, hogy a sikertelenség érzése csökkenjen bennük.

A kiégés szindróma prevenciójában és kezelésében fontos momentum, hogy időben fel kell ismerni a problémát, a kimerülés tüneteit, reális célokat tüzzünk ki, segítsük a pozitív gondolkodást, biztosítsunk relaxációs lehetőségeket, illetve komoly probléma esetén pszichoterapeuta bevonása is szükséges lehet. A munkahelyeknek a túlterhelés csökkentésére is kellene próbálkozásokat tenni, kommunikációs tréningeket, továbbképzési lehetőségeket kellene biztosítani, illetve fontos, hogy az ápolókban erősítsék a fontosság, hasznosság érzését. (Nagy, 2007)

Kutatásom rávilágít, hogy célszerü lenne az egészségügyi intézményekben az ápolók mentálhigiénés gondozása, illetve a kiégés prevenciós lehetőségeinek kihasználása. Erre szükség lenne mind az ápolás minőségének javitása, mind az ápolók lelki egészségének megőrzése érdekében is. Bár tudom, hogy a burnoutszindróma az egészségügyben egy mindenki által ismert fogalom, remélem kutatásommal segítettem felhívni arra a figyelmet, hogy a kiégés egy valóban jelen lévő probléma és nagyobb mértékü annál, mint amekkora hangsúlyt fektetnek rá az egészségügyi intézményekben.

\section{Felhasznált irodalom}

1. Bordás A. (2010): A kiégés-szindróma a külföldi és a hazai szakirodalomban. Educatio, 2010/4, pp. 666-672.

2. Csabai M. - Molnár P. (1999): Egészség, betegség, gyógyítás. Springer Orvosi Kiadó Kft.

3. Hárdi I. (1998): Pszichológia a betegágynál- Orvos, nővér és a beteg. Medicina Könyvkiadó Rt. Budapest.

4. Helembai K. (2010): Általános ápoláslélektan. Medicina Könyvkiadó Zrt, Budapest.

5. Hézser G. (1996): Miért? Rendszerelmélet és lelkigondozó gyakorlat. Kálvin Kiadó, Budapest.

6. Kulcsár ZS. (2002): Egészségpszichológia. ELTE Eötvös Kiadó Budapest. 
7. Nagy E. (2005): A lelki túlterheltség szociálpszichológiai megközelítése. LEGE ARTIS MEDINIAE- Orvostudományi Továbbképző Folyóirat, 15(2):160-163.

8. Nagy E. (2007) Ph.D értekezés: Egy segítő foglalkozás képviselőinek pályaképe, a kiégés szempontjából. Debreceni Egyetem.

9. Ónody S. (2001): Kiégési tünetek (burnout szindróma) keletkezése és megoldási lehetőségei. Új Pedagógiai Szemle, 51 (5), 80-85.

10. Pálfi F. (2006): „Amikor kihült a láng”- A kiégés vizsgálata ápolók körében. IME IV. évfolyam 10. szám, 31-35. oldal.

11. Pálfi F. (2007) Ph.D értekezés: Ápolói és gondozói magatartások alakulása különböző ellátási helyzetekben, különös tekintettel a kiégés jelenségére. Pécsi Tudományegyetem.

12. Szicsek M. (2004): A kiégés és a pszichológiai immunkompetencia összefüggései az ápolói munkában. In: KHARÓN Thanatológiai Szemle VIII. évf. 1-2. sz. 2004/1-2. 88-131.

13. Tandary - Kovács M. (2010): Érzelmi megterhelődés, lelki kiégés az egészségügyi dolgozók körében. Semmelweis Egyetem Mentális Egészségtudományok Doktori Iskola, $(\mathrm{PhD})$ értekezés. Budapest.

\section{Nagy Ildikó}

2011-2015 között a Debreceni Egyetem Egészségügyi Karán tanult diplomás ápolóként, jelenleg a Debreceni Egyetem Népegészségügyi Karán Népegészségügyi Msc képzésen folytat tanulmányokat. A Verzár Frigyes Szakkollégiumnak és az Evangélikus Roma Szakkollégiumnak is tagja. 2013 óta vesz részt a Debreceni Egyetem Tehetséggondozó programjában. Tanulmányai alatt több publikációja is megjelent, illetve több nemzetközi és hazai konferencián is tartott előadást. Kutatómunkája központjában a burn- out szindróma vizsgálata áll, melyet egyetemi hallgatók és ápolók között is vizsgál. Munkája legmagasabb eredményeként a XXXII. OTDK Társadalomtudományi Tagozat Egészségügyi tanulmányok szekciójában I.helyezést ért el. 
